\title{
Essence and Concept of Capitalization of Enterprises its Types and Methods of Evaluation
}

\author{
By Lyudmila Pronko ${ }^{1}$, Tatyana Kolesnik ${ }^{2}$, Oksana Samborska ${ }^{3}$
}

\begin{abstract}
The historical aspect of the development of scientists' views on the company's capitalization is studied in the work, the stages of development of the concept of cost-oriented management are determined. The role and place of market capitalization in the system of indicators of cost-oriented management are determined, modern methodical approaches to the assessment of the value of the enterprise taking into account the indicator of market capitalization are given. The fundamental differences between the areas of application of indicators of market value of the enterprise and market capitalization are established. The current problems of the Ukrainian economy that limit the widespread use of market capitalization in the valuation of companies are outlined, and proposals are made on the feasibility of valuing Ukrainian companies in terms of real capitalization. The importance of enterprise capitalization in the development of a market economy is emphasized. The evolution of the views of foreign scientists on the capitalization of enterprises has been studied. It is established that the economic essence of the capitalization of enterprises, as well as any asset, is the present value of future income generated by this asset. Bringing future income to the present is a process of discounting. The theory of capitalization of the company in its modern context began to be formed by neoclassical economists from the end of the XIX century. and gained popularity in the second part XX century. The theory of capitalization has given impetus to well-known neoclassical theories of corporate finance, such as the irrelevance theorem, risk theory, investment portfolio optimization theory, arbitrage pricing theory, and so on. It is established that according to the theory of capitalization, the capitalization of the enterprise and the market value of the enterprise are identical concepts, although the methods of their calculation differ. The theory of capitalization has given impetus to the development of many modern financial theories, which are currently under development and improvement.
\end{abstract}

Keywords: valuation, evaluation, capitalization, methods of evaluation, real valuation, market price

\section{Introduction}

The problem of capitalization is very relevant from a theoretical and practical point of view, because there is a connection between capitalization and economic growth. Economic development today is seen as a process of transition from an administrativecommand economy to a market one. But in reality, there is a transition from a mixed economy based on administrative-command principles to a mixed economy based on market principles.

Thus, market transformation of the economy is the creation of a capitalist economy or

${ }^{1} \mathrm{PhD}$ in Economics, Associate Professor, Department of Administrative Management and Alternative Energy Sources, Vinnytsia National Agrarian University, Ukraine

${ }^{2} \mathrm{PhD}$ in Economics, Associate Professor, Department of Administrative Management and Alternative Energy Sources, Vinnytsia National Agrarian University, Ukraine

${ }^{3} \mathrm{PhD}$ in Economics, Associate Professor, Department of Administrative Management and Alternative Energy

Sources, Vinnytsia National Agrarian University, Ukraine 
capitalization of the economy. The topic of capitalization has not been thoroughly studied and considered. There is a theoretical problem of determining the essence of capitalization in today's conditions, because in the literature there are different approaches to its definition.

\section{Literature Review}

Many works of famous scientists of the XVIII-XIX centuries were devoted to the problem of capitalization. According to them, the concept of capitalization is derived from the concept of "capital" (capital - from the Latin "capitalis", which means the main one). At the beginning of the development of social production, capital was considered by economists as property, wealth. Mercantilists focused on the monetary form of capital, Jean-Baptiste Say, by capital he meant the amount of values that made it possible to carry out production.

Adam Smith, David Ricardo, Karl Marx defined capital as value that brings added value. K. Marx noted that capital is a tool, and raw materials and material products, and a certain amount of goods and livelihoods. In addition, he wrote that capital is not a thing, but a production relation, and therefore considered it as an instrument of exploitation of hired labor.

\section{Methodology}

History and facts are the basis of economics, and facts cannot tell their own history. Economic analysis should be added to history, because only through the development and verification of economic theories can we organize and organize a chaotic mixture of data and facts in a clear view of reality. This is an approach that begins with a set of assumptions people, firms or the economy as a whole.

\section{Case Studies}

Thus, capitalization is the conversion of value added or profit into capital. A. Marshall defined capital as a set of things without which production could not be carried out with equal efficiency, but which are not free gifts of nature.

Thus, we can identify certain evolutionary stages of interpretation of the essence of "capitalization":

1st period - XVII beginning of XIX century. According to Marxist theory, capitalization on the one hand is the process of accumulating capital by capitalizing profits, which is intended to expand production, and on the other - the flow of future value, which is determined by interest rates, as capitalization of market value.

2nd period - late nineteenth - early twentieth century. Representatives of the neoclassical direction of economic theory supplemented their predecessors, and capitalization understood the process of creating and accumulating value, which brings an effect with a return equal to the interest rate, the size of which is determined by certain capital productivity.

The Keynesian era considered capitalization as an economic category in a new aspect. 
According to her theory, capitalization is the accumulation of capital through money circulation. At the end of the production cycle, part of the generated cash income is consumed, and the other part is directed to the maintenance and development of assets, accumulates.

3rd period - the end of the twentieth century. From the second half of the twentieth century the process of researching the essence of capitalization ceases, because this term is almost never used, not only in the domestic scientific literature, but also in foreign;

4 th period - the present. There is a growing interest of both domestic and foreign scientists in the essence and importance of capitalization of the enterprise as an economic category. In the modern economic literature, the main focus is on the ability of capital to bring its owner income.

In a market economy, it is not possible to achieve economic growth without the concentration of capital, so in the classical sense, the term capitalization means the reinvestment of profits received by the firm, the conversion of profits into additional capital (Andriychuk V.G. 2007).

Modern scholars interpret the term capitalization differently. It is often used in such a sense as the assessment of the value of the firm on the basis of fixed and working capital; assessment of the value of the firm on the basis of the market value of its shares and bonds or on the basis of annual profits (Evaluation company.PRO-evaluation. Available at: http://www.proocenka.ru/).

The term market capitalization, which means the value of all shares of a joint-stock company, the price that the market is willing to pay for the company in the event of its sale, is also widely used. Some scholars, when talking about capitalization, mean the financial market and understand capitalization as the estimated value of those securities that are in circulation in the market.

In banking, this statement is understood as an increase in the bank's equity. The classical definition characterizes the concept of "capitalization" as the conversion of value added or profit into capital.

Thus, all these statements of one definition contradict each other, because one characterizes the income, which is later converted into a resource, and the other determines the total value of resources or the company. Therefore, it is advisable to investigate and resolve these issues. According to the classical statement, capital is understood as value, which brings additional value, which can be embodied both in material form and in the personal factor or income.

Thus, capital can be human abilities and factors, and knowledge, and material resources used to obtain added value. And the process of converting available resources into value, which brings additional value and is capitalization.

This approach allows to distinguish between real and fictitious, direct and reverse capitalization, capitalization of various industries (industry, agriculture, banking, financial market, etc.) and areas.

Real capitalization - the transformation of value embodied in material and other values into a source of growth of this value. Fictitious capitalization - real capital represented by securities.

Direct capitalization is understood as the process of transforming a resource involved in market circulation into value, which brings additional value [6]. 
The reverse capitalization is the conversion of value added into capital. That is, when valuing capital by income, the reverse fictitious capitalization is carried out, and the real value that brings this income may differ significantly from the fictitious capitalized. If the level of profitability of the enterprise grows rapidly, then the level of their fictitious capitalization arises from the assessment of the profitability itself.

In the production process there are capitalization of factors of production, capitalization of the production process and capitalization of production results. The essence of the capitalization of factors of production is the need to use them in market conditions in capitalist production. The capitalization of the production process is characterized by the efficiency of use of all components in order to increase value added and increase profits. Capitalization of production results is a direct transformation of value created into new capital (Baranovskiy 2003) argues that capitalization is the market value of the company calculated by multiplying the total number of shares of the issuer by the average price of the best quotations of shares for sale.

Scientist (Bryukhovetska 2007) notes that capitalization is the use of part of the value added to expand production, or it is the process of investing part of the profits in securities and making a profit on them in the form of interest.

Capitalization, or capitalized surplus value, formed a fund of capitalist accumulation, which with capitalist development was used mainly for the acquisition of additional productive resources and labor. Today, this fund is also used for research, obtaining new information, applying new management methods and organizing production.

In the economic encyclopedia capitalization is seen as a part of the added value used to expand capitalist production, as well as the process of investing part of the income in securities and making a profit on them in the form of interest.

Capitalization of income (Dictionary of modern economics Macmillan 2000) in the modern dictionary of Macmillan's economy, is the expenditure of profit to increase capital, the conversion of profit into capital [8].

Thus, the term "capitalization" can characterize the growth of equity through own funds, bank loans, budget financing, etc., or play the role of distribution and use of profits, ensuring the development of the enterprise, take into account the recognition of costs as assets, determine the value of net assets organization or the amount of share capital, the value of the property according to its profitability, to convert additional value into capital. In modern conditions, the concept of market capitalization has become widely used, which in essence determines the market price on the stock exchange of registered shares of the company or all its shares, it is the value that can significantly exceed the value of assets on the balance sheet. This is due to the fact that not all assets that have value are included in the balance sheet of the enterprise, such as skilled workers, business reputation, demand for products, etc.

But at the time of sale of shares of an enterprise, its value can both increase and decrease, depending on the demand and supply of shares in the market. Thus, it can be argued that capitalization (capitalization) - an estimate of the value of the enterprise, land, securities and other property, by determining the amount of expected income for the period during which it is planned to use.

More fully the economic meaning and essence of capitalization is manifested in certain functions: 
- strategic - the choice of promising areas of the enterprise, which determine the longterm prospects for achieving competitive advantages of the enterprise and maintaining its position in the market;

- forecast - assessment of the potential and planning of the future state of the enterprise; - evaluation - analysis of financial and economic activities of the enterprise, identification of available reserves and compliance with international efficiency criteria;

- distribution - effective distribution of resources involved in the development and expansion of the enterprise, the implementation of the capitalization process, the balance of economic activity of the enterprise;

- mobilization - attracting resources to expand production, achieve the goals of the enterprise;

- information - collection and dissemination of information about the economic stability and investment attractiveness of the enterprise at the micro, micro and macro levels;

- stimulating - stable development of economic, scientific, technical and entrepreneurial activities.

Thus, capitalization is the process of accumulating capital of an enterprise by capitalizing its own income, attracting bank loans and using financial leasing, infusing capital from other sectors of the economy, attracting foreign direct investment, and moving capital from less efficient owners to more efficient ones. The accumulation of capital in certain areas, capitalization, is an important factor in the market transformation of the country.

It is also obvious that the accumulation of capital is directly related to the use of money capital and its transformation into productive capital - machinery, equipment, materials, etc. Then there is a transition of productive capital into money. In the process of such a cycle under effective management, the market value (capitalization) of the enterprise increases and opportunities are created to increase production efficiency.

Having made a comparative analysis of the essence and concept of capitalization, we define the main methods of assessing the market value of enterprises.

The value of an enterprise is a monetary measure of its economic value, quality and social utility. Economic value and social utility characterize the ability of an enterprise to produce a certain amount of products, works and services and bring the appropriate amount of income and profit to its owner. That is, the profitability of production of works and services minus the annual inflation rate should ensure the economic development of production activities and increase wages.

Under the quality of the enterprise understand the actual level of its physical, moral, economic and operational wear. The first three types of wear depend on the service life and specifics of the production activities of the enterprise, the last - on the professionalism and efficiency of the management staff, as well as market conditions.

An in-depth analysis of the value of the enterprise and its properties (capital intensity, value of economic resource) allows to determine its variety:

- real (real, objective) value of the enterprise;

- authorized (subjective) value of the enterprise;

- capitalized (stock, paper) value of the enterprise, which exists in the form of joint stock companies.

The actual or real value of the enterprise - internal and external objectively determined value, or in other words - is a reasonable, fair, most probable value of the analyzed object. 
It combines the real value of all available production resources of the enterprise and the value of the land where it is located.

The integrated characteristics of the production resources of the enterprise are based on a number of interrelated indicators: production capacity, volume of output, the amount of income and profit. Scientifically-based capitalization of the last of the indicators taking into account the actual integrated depreciation of production resources allows to determine the real (real) value of the enterprise.

Integral wear is a consequence of physical, moral and economic wear of production resources. Accounting for physical depreciation makes it possible to exclude from the nominal real value of the resources used the amount of money that during the operation were returned to the owner of the enterprise in the form of depreciation. By taking into account the moral and economic depreciation of production resources of the enterprise from their real value are calculated losses of that part of the resources, the restoration or modernization of which is economically unprofitable.

Significant influence on the size of the real (real) value of the enterprise has the location of the land it occupies, its size, configuration, access roads, proximity to central highways, the availability and quality of infrastructure communications: energy, heat, gasification, availability of hot and cold water, sewerage, telephones, etc.

Today, the assessment of the enterprise and its real value are taken as synonyms, which is not true. In an environment where there are many evaluators and evaluation methods, the probability of error increases.

The assessment of the enterprise can be professional, expert and delicate. In the first case, the assessment is performed by qualified, certified and licensed specialists; in the second mainly as a result of intuitive calculations, but on the basis of certain knowledge and experience. The delinquent assessment of the enterprise is issued by non-specialist experts. In addition to the above, the assessment of the enterprise is predictable and calculated. An example of the envisaged assessment is expert assessment and assessment as a result of using the method of "brainstorming"; estimated assessment is the assessment of professionals and specialists. Estimated assessment of the enterprise can be design, regulatory, planning, forecast and operational (market). The type of assessment depends only on what initial data the assessor uses in the assessment.

A characteristic feature of the assessment, which is recognized as the real (real) value of the enterprise is that it can be authorized and unauthorized, individual and collective, but can't be formal, unreasonable and unfair (Gryaznova A.G., Fedotova M.A., Eskindarov M.A., Tazikhina T.V. 2009).

For joint-stock companies whose shares are traded on the stock exchange, the real value of such business structures is the stock (paper) value of the company. "Capitalization" is synonymous with paper value in public joint stock companies.

Indicators of capitalization of joint-stock companies are equated to indicators of their real market value. The paper capitalization of JSCs is significantly influenced by international, political, social, psychological and other factors, which prevents the objective reflection of the real value of such objects.

The capitalization of a JSC depends on the market situation and practically does not depend on the personal characteristics of the person who evaluates it. Thus, capitalization, valuation and fair value of the enterprise are different concepts. 
Theoretically, a one-time valuation or current capitalization of an enterprise may correspond to its real value, but the probability of such an identity is very small. As a result, the question arises: in which cases can be limited to a single estimate (indicator of authorized value) of the enterprise, and in which it is advisable to spend an additional amount of money to obtain an indicator of real (fair) value by a specially conducted statistical experiment.

In some cases, for large companies, their projected real value needs to be determined by a standard method of expert judgment, with experts being owners, top managers, representatives of intermediary firms engaged in the sale and resale of enterprises, and business appraisers and expert auditors. industrial and land ownership. Sometimes, instead of the method of expert assessment, when deciding on the feasibility of conducting a statistical study of the fair value of the enterprise more effectively use the method of "brainstorming" of competent persons.

The essence of such an experiment is that a group (12-15 people) of independent professional appraisers is tasked to evaluate the company. As a result of the legalized estimate received by them the statistical analysis is carried out: the law of distribution, mathematical expectation, standard deviation and limits of fluctuations of the defined estimation are established. In our opinion, the mathematical expectation of the focus sample of professional evaluation most accurately reflects the fair value of the analyzed enterprise

If it is impossible to establish the law of distribution and mathematical expectation of the given estimations according to the given estimation of qualified experts, then for real cost accept arithmetic average value of the received estimations. Thus, the value of the enterprise, determined by the method of statistical experiment can't be called authorized and real.

It should be borne in mind that the statistical analysis of "fake", low-quality estimates of the enterprise will allow to obtain a "fake" real value. Therefore, of particular interest is the examination (audit-analysis) of methods that determine the maximum and minimum assessment of the enterprise. The range of fluctuations of these results depends on the individual abilities and creative abilities of evaluators in selecting and preparing to calculate the necessary initial data for evaluation; from the level of standardization of procedures, evaluation technology and frequency of its implementation.

The concept of capitalization is derived from the concept of "capital". Economics has developed many definitions of capital (capital - from the Latin "capitalism", which means the main). At the beginning of the development of social production, capital was considered by economists as property, wealth. Mercantilists placed the main emphasis on the monetary form of capital, Jean-Baptiste Say, by capital he meant the sum of values that makes it possible to carry out production (Sei J. 1968).

Adam Smith and David Ricardo, Karl Marx defined capital as value added (Marx 1968) noted that capital is a tool, and raw materials and material products, and a certain amount of goods and livelihoods. In addition, he wrote that capital is not a thing, but a production relationship, and therefore considered it as an instrument of exploitation of hired labor.

A. Marshall defined capital as a set of things without which production could not be carried out with equal efficiency, but which are not free gifts of nature.

In the modern economic literature, the main focus is on the ability of capital to bring its 
owner income. In a market economy, it is not possible to achieve economic growth without the concentration of capital, so in the classical sense, the term capitalization means the reinvestment of profits received by the firm, the conversion of profits into additional capital (Andriychuk V.G. 2007).

Modern scholars interpret the term capitalization differently. It is often used in such a sense as the valuation of the firm on the basis of fixed and working capital, the valuation of the firm on the basis of the market value of its shares and bonds or on the basis of annual profits (Dictionary of modern economics Macmillan 2000). The term market capitalization, which means the value of all shares of a joint-stock company, the price that the market is willing to pay for the company in the event of its sale, is also widely used.

In addition, capitalization may be insufficient, sufficient or excessive, depending on the ratio between the economic capital of the enterprise and the actual existing at the moment. Excess capitalization often causes dissatisfaction of investors, because there is an inefficient use of monetary resources: free funds are not invested, do not bring additional income, and - are capitalized.

Insufficient capitalization or subtlety most often occurs when the enterprise is financed by borrowed funds (Andriychuk V.G. 2007).

In the economic literature and practice there are a number of methods of capitalization of the enterprise, the main of which are:

Split rate capitalization - interest and discount rates are used to estimate the projected cash flows for one company.

Capitalization of earnings is the calculation of the real value of the net profit that is planned to be obtained in the future.

Straight line capitalization is a method of calculating the capitalization ratio for real estate by adding a rate of return on capital to the interest rate.

Direct overall capitalization is a method based on dividing the net operating income by the ratio obtained by comparing the income that brings these objects with the prices of their sale.

The variety of methods used allows us to consider capitalization from different points of view:

- first, the market capitalization is determined by multiplying the exchange value of shares by their number;

- Second, capitalization is the result of the conversion into equity of all long-term liabilities of the enterprise.

The market capitalization of a JSC is the value of all its shares, the price that is set by quotation on the stock exchange (excluding changes in the share price during the purchase process). The capitalization of the enterprise is determined by multiplying the share price by their number (only ordinary shares are taken into account, not preferred ones). In other words - market capitalization - the price that the market is willing to pay for the company. Thus, capitalization (capitalization) - an estimate of the value of the enterprise, land, securities and other property, by determining the amount of expected income for the period during which it is planned to use. 


\section{Conclusion}

Analysis and detailed study of such important market terms as "value", "valuation", "capitalization" and "price" allowed us to draw the following conclusions: value - determining the economic value of resources and the enterprise at the moment, and capitalization - market valuation of the enterprise, taking into account all its property and resources for the period of their use. Valuation and price are tools for determining value and capitalization. Therefore, in the conditions of development of market relations, attention should be paid to the capitalization of enterprises, because due to the accumulation of capital, capitalization becomes an important factor in the market transformation of the national economy.

Modern enterprise management requires a thorough study of the essence of key categories and the possibilities of their application in Ukrainian realities. The value of the market capitalization indicator is that it reflects many aspects of the company's positioning in the market, the possible selling price, performance, and development potential, and market expectations for future prospects. But such a comprehensive description of the enterprise in size and dynamics of its market capitalization is possible only if a developed effective stock market institution. The current realities of the Ukrainian economy limit the widespread use of market capitalization in assessing the current state of the enterprise and its future prospects. However, the assessment and control of real capitalization in a deep economic crisis are pressing issues and require increased attention. Analysis of scientific sources on the capitalization of enterprises makes it possible to consider this concept through the prism of different approaches: - the transformation of income (value added), profit into capital, which is called real capitalization; - an indicator of the market value of the company in the stock market, which is defined as the product of the sum of the issuer's securities issued at their market price (market capitalization); - the process of formation of fictitious capital on the secondary market in the form of shares, bonds, derivatives. The deep economic crisis, the underdevelopment of the stock market and the high price of borrowed resources should draw attention to the real capitalization of the enterprise, the process of accumulation of equity by businesses. Modern economic realities of Ukraine encourage owners and managers to draw attention to the preservation of accumulated real capital through the introduction of anti-crisis measures.

\section{References}

Andriychuk V.G. 2007. Capitalization of agriculture: the state and economic regulation of development. Aspect-Polygraph LLC. 216.

Andriychuk V.G. 2005. Capitalization of domestic agriculture: essence, directions, mechanisms and first assessments of implementation // Economics of agro-industrial complex. 7: 69 -74.

Gryaznova A.G., Fedotova M.A., Eskindarov M.A., Tazikhina T.V., Ivanova E.N., Shcherbakova O.N. 2009. Valuation of the enterprise (Businnes). Prior. 480.

Kozur Yu. V. 2008. The cost of the company. Evaluation and management decisions. Alfa-Press. 380.

Marx K., Engels F. 1968. Essays. 25(2): 380.

Evaluation company.PRO-evaluation. Available at: http://www.proocenka.ru/.

Jeffrey D. Jones, Thomas L. 2007. Business evaluation manual West. 540

Sei J. 1968. A treatise on Political Economy. 58. 
Business Valuation Standards: A profitable approach to business valuation. Available at: http://www.cfin.ru/ finanalysis / value / asa / bvs- 7.shtml.

Murrin J., Koller T., Coeland T. 2008. Cost of companies: evaluation and management. Olympus-Business. 345.

Ratushna Yu. S. 2004.The concept of the category "entrepreneurial capital" and its economic content. Customs. 1: 91.

Fishman Jay, Pratt Shannon Griffith Clifford, Wilson Kate. 2009. A Guide to Business Valuation. 790.

Baranovsky A. 2003. Undercapitalized economy. Mirror of the week.42:467.

Bruhovetskaya N. Yu. 2007. Approaches to determining the capitalization of the enterprise. 31(1): 224-229.

Grigoriev V.V. 1999. Characteristics of methods of income approach. Income capitalization method. City property. 4 (20): 9-12.

Gritsenko A.A. 2006. Capitalization of the economy: problems and prospects. Economic theory. 2: 91-110.

Economic Encyclopedia: in three volumes. 1. 2000. 864.

Dictionary of modern economics Macmillan. Artek. 2000. 640.

Samborska O. 2020. Economic analysis for forecasting and prospective planning of economic processes of local self-government. The scientific heritage 46(1).21-28.

Pronko L., Rossokha V. 2010. Development of property relations in agricultural enterprises: Monograph. NNC IAE.236. 